\title{
SISTEM INFORMASI MANAJEMEN KEPELABUHAN DAN PELAYARAN TERHADAP FAKTOR-FAKTOR KESELAMATAN PELAYARAN DI KABUPATEN KARIMUN PROVINSI KEPULAUAN RIAU
}

\author{
MANAGEMENT AND PAYMENT MANAGEMENT INFORMATION SYSTEMS ON \\ SAFETY FACTORS OF DELIVERY IN KARIMUN DISTRICT RIAU ISLANDS \\ PROVINCE
}

\author{
Tri Mardalena \\ Program Studi Manajemen Kepelabuhan dan Pelayaran, Universitas Karimun \\ mardalena.tri@gmail.com
}

\begin{abstract}
Abstrak
Penelitian ini bertujuan untuk mengetahui faktor mana yang mempengaruhi secara signifikan terhadap faktorfaktor keselamatan pelayaran di Kabupaten Karimun. Bentuk analisis statistik yang digunakan adalah regresi linear berganda dengan 3 (tiga) uji asumsi klasik..Penelitian dilaksanakan pada perusahaan pelayaran di Kebupaten Karimun, waktu penelitian mulai dari tanggal 4 November 2017 sampai dengan tanggal 4 Januari 2018. Populasi target dalam penelitian adalah perusahaan swasta yang bergerak di bidang pelayaran, sedangkan populasi terjangkau adalah 4 perusahaan pelayaran swasta dengan 36 responden, dimana teknik pengambilan data secara sensus.Dari hasil analisa uji $t$ diperoleh kesimpulan, bahwa variabel bebas community development (X1) berpengaruh positif dan signifikan terhadap variabel terikat faktor-faktor keselamatan pelayaran (Y), dimana nilai t hitung (2,322) dengan signifikansi 0,027 > dari nilai t tabel (2.035), sedangkan variabel bebas networking (X2) tidak berpengaruh positif dan signifikan terhadap variabel terikat faktor-faktor keselamatan pelayaran $(Y)$ dimana nilai $t$ hitung $(-1,832)$ dengan signifikansi $0,076<$ dari nilai $t$ tabel (2,035). Sementara dari hasil uji f diperoleh kesimpulan, bahwa variabel bebas community development (X1) dan networking (X2) tidak berpengaruh secara bersama-sama (simultan) terhadap variabel terikat faktorfaktor keselamatan pelayaran $(Y)$, dimana nilai f hitung $(2,720)$ dengan signifikansi $0,081<$ dari nilai $f$ tabel $(3,28)$.
\end{abstract}

Kata kunci: Community Development, Networking. Faktor-faktor Keselamatan Pelayaran

\begin{abstract}
This study aims to determine which factors significantly effect Shipping Safety factors in Karimun Regency. The form of statistical analysis used is multiple linear regression with three (3) classic assumption tests. This study was conducted on shipping companies in Karimun Regency, the time of research starting from Nov 4, 2017 to Jan 4, 2018. The target population in the study was private shipping companies, while the affordable population were 4 private shipping companies with 36 respondents, cencus data collection techniques. From the result of the t-test analysis, it can be concluded that the independent variable of Community Development (X1) has a positive and significant affect on the dependent variable of Shipping Safety (Y), where the value of $t$ count $(2,322)$ with a significance of 0,027 > from the value of t table (2,035), while the independent variable Networking (X2) does not have a positive and significant effect on dependent variable Shipping Safety factors $(Y)$, where the value of $t$ count $(-1,832)$ with a significance of $0,076<$ from the value of $t$ table (2.035). Meanwhile, from the result of the f-test, it can be concluded that the independent variable Community Development (X1) and Networking (X2) do not have a simultaneous effect on the dependent variable of Shipping Safety factors $(Y)$, where the value of the $f$ count $(2,720)$ with a significance of $0,081<$ from the $f$ table $(3,28)$.
\end{abstract}

\section{Keyword : Community Development, Networking, Shipping Safety factors}

\section{PENDAHULUAN}

Perkembangan dan kemajuan pesat di bidang industri dan teknologi informasi menyebabkan perubahan besar di berbagai aspek dan bidang kehidupan manusia. Kondisi ini 
mendorong organisasi kepelabuhanan dan pelayaran untuk mengikuti dan berkembang sejalan dengan perkembangan dan kemajuan tersebut, yang berarti operasional organisasi menjadi semakin kompleks dan persaingan akan semakin ketat. Hal ini mendorong pula terjadinya pergeseran-pergeseran paradigma di dalam organisasi terutama di bidang keselamatan pelayaran.

Dunia pelayaran sangatlah luas dan penuh dengan tantangan dan bahaya. Sejak jaman dulu hingga saat ini, laut dipenuhi dengan lalu lintas yang sangat ramai. Bahkan bahaya pun seringkali terjadi. Guna mengendalikan tingkat bahaya dalam dunia pelayaran, maka disusunlah suatu sistem manajemen keselamatan pelayaran yang disebut sebagai ISM Code (International Safety Management Code) yang dikeluarkan oleh IMO (International Maritime Organization), yang merupakan standar yang disusun dari beberapa kesepakatan dan regulasi yang menyangkut keselamatan dan pencegahan pencemaran lingkungan kelautan, misalnya : HSC Quality Manual, HSC Fleet Manual, HSC Crew Management Manual, SOLAS, MARPOL 73/78, ILO 147, Classification Society Survey Rules, Regulasi dan peraturan lain yang berlaku. ISM Code merupakan panduan, bukan berisi petunjuk pengoperasian kapal, yang menuntut organisasi untuk menyusun sistem manajemen keselamatan pelayarannya sesuai kapal yang dimiliki dan digunakan. Keseluruhan manualnya harus mencakup pengendalian kerja di kapal dan seluruh pendukungnya di darat. Dapat berbeda antara satu perusahaan dengan perusahaan lainnya, namun tetap mengacu pada aturan ISM Code. Sertifikat akan diterbitkan untuk setiap kapal bila pelaksanaan sudah diverifikasi memenuhi persyaratan standar ISM Code. Sertifikat manajemen keselamatan pelayaran ( Safety Management Certificate ) berlaku 5 tahunan dan selama masa tersebut akan dilakukan audit oleh penerbit sertifikat.

Pemahaman arti "keselamatan" dalam standar ini adalah pernyataan bahwa resiko bahaya pada manusia dan kerusakan pada kapal serta laut dapat ditekan pada tingkatan yang ditentukan. Atau dapat diartikan sebagai "Bebas dari bahaya", baik pada kapal-manusialingkungan. Keamanan pelayaran merupakan faktor utama dalam sistem manajemen untuk pelayaran. Bahaya pelayaran merupakan faktor yang tidak dapat tidak terjadi sama sekali, namun dapat dikurangi dan ditekan secara terus menerus dengan berbagai upaya, yaitu : melaksanakan prosedur kerja dengan konsisten, melakukan komunikasi yang tepat dan benar, menggunakan alat-alat pelindung diri yang tepat, fasilitas keselamatan yang aman, tidak 
rusak dan masih berfungsi, menyusun perencanaan kerja dan pemantauan hasil kerja, melatih personil secara rutin.

Dalam pelaksanaan sistem manajemen keselamatan pelayaran, perusahaan pelayaran perlu menunjuk personil yang bertanggungjawab memantau pelaksanaan sistem tersebut bagi seluruh personil di semua tingkatan dalam suatu organisasi (perusahaan). Sasaran yang harus dibuat perlu mencakup: Tersedianya prosedur operasional kapal dan pencegahan pencemaran lingkungan, tersedianya panduan darurat untuk segala resiko bahaya, adanya peningkatan berkelanjutan secara terus menerus pada seluruh personil, baik di darat (perusahaan/organisasi) maupun di laut (personil kapal) dalam penanganan pencegahan bahaya, kondisi darurat dan pencegahan pencemaran lingkungan. Sistem ISM Code ini dianggap penting, ada beberapa alasan yang mendasari adalah : seringnya terjadi kecelakaan di laut, gagalnya pelaksanaan prosedur dan instruksi kerja, tidak berhasilnya melatih personil, sehingga sistem manajemen keselamatan pelayaran ini mewajibkan perusahaan untuk :menyusun kebijakan keselamatan dan pencegahan pencemaran lingkungan, menentukan posisi personil dalam suatu struktur, baik untuk posisi di darat (perusahaan) maupun di laut (kapal), termasuk juga untuk personil yang ditunjuk sebagai penanggungjawab sistem, uraian tugas dan wewenang jabatan personil, menuliskan prosedur dan instruksi kerja di darat (perusahaan), pengoperasian kapal dan pencegahan pencemaran lingkungan. Menyusun program pemeliharaan, pengujian dan pemeriksaan. Merencanakan program penanganan kondisi darurat secara terus menerus. Menyusun prosedur penyusunan laporan atas kecelakaan dan ketidaksesuaian yang terjadi. Menjalankan pelatihan bagi seluruh kru kapal dan memastikan seluruh personil telah terlatih. Menjalankan audit internal dan tinjauan manajemen. Pengendalian dokumen dan rekaman.

Kunci awal yang harus dipahami dalam pelaksanaan standar ini adalah “3 C”, yaitu :

Commitment: langkah awal untuk memulai pelaksanaan standar, mulai dari pimpinan tertinggi hingga seluruh personil di bawah. Commonsense: bahwa yang dijalankan adalah hal yang bisa dilakukan. Namun bila belum dimengerti, bertanyalah pada personil yang sudah mengerti. Communication : komunikasi yang menyeluruh tanpa batasan waktu.

Keuntungan menjalankan manajemen keselamatan pelayaran: Menumbuhkan kesadaran akan mutu/keselamatan pelayaran. Meningkatkan efisiensi, produktivitas, jaminan, dan meningkatkan keuntungan, kepercayaan pelanggan, kepuasan pelanggan. Peningkatan berkelanjutan. Meningkatkan performa perusahaan. Meningkatkan moral personil. Tantangan 
yang akan terus dihadapi adalah: Menekan terjadinya kesalahan operasional. Menekan terjadinya kecelakaan manusia. Upaya untuk terus menjaga dan melindungi manusia dan lingkungan. Pengendalian atas pelaksanaan sistem dan ketidaksesuaian. Dapat digunakan sebagai alat bantu pemasaran. Pengakuan secara internasional. Menjembatani antara keinginan klien dengan perusahaan, terkait dengan mutu pelayanan.

Dalam penelitian ini, ingin mengkaji faktor-faktor yang mempengaruhi keselamatan dalam organisasi kepelabuhanan dan pelayaran dengan community development. Kemudian bagaimana pandangan dalam konsep community development tersebut dikembangkan dengan hubungan kemitraan (networking). Dengan melakukan analisis regresi linier berganda diharapkan akan didapatkan faktor-faktor mana yang dapat membentuk hubungan terhadap perusahaan/organisasi kepelabuhanan dan pelayaran yang unggul dan kompetitif sehingga diharapkan akan dapat menjelaskan dimana posisi tanggung jawab sosial dapat ditingkatkan karena pengelolaan community development dan membangun kemitraan yang efektif dan berkesinambungan memungkinkan perusahaan/organisasi kepelabuhanan dan pelayaran untuk memiliki keunggulan kompetitif sehingga mampu bersaing di pasar global dan internasional.

\section{Identifikasi Masalah}

Untuk menyusun suatu manajemen informasi kepelabuhanan dan pelayaran berkaiatan dengan keselamataan pelayaran yang unggul dan mampu bersaing dapat dianalisis berdasarkan atas beberapa faktor. Faktor-faktor tersebut antara lain adalah bagaimana perusahaan/organisasi tersebut mampu:

a. memberdayakan masyarakat sekitar ;

b. peduli terhadap lingkungan ;

c. memiliki jaringan dan kerja sama dengan perusahaan lain yang saling menguntungkan serta berkesinambungan.

\section{Pembatasan Masalah}

Berdasarkan identiffikasi masalah, maka penelitian ini menggunakan pemberdayaan masyarakat (community development) dan networking untuk melihat hubungannya secara simultan terhadap faktor-faktor keselamatan pelayaran yang baik dan benar dengan pertimbangan mudah membangun indikator sebagai sumber data penelitian. 


\section{Perumusan Masalah}

Sesuai dengan hubungan yang telah dibatasi, maka dibangun rumusan masalah sebagai berikut:

a. Apakah community development memberikan pengaruh positif dan signifikan terhadap faktor-faktor keselamatan pelayaran?

b. Apakah networking memberikan pengaruh positif dan signifikan terhadap faktor-faktor keselamatan pelayaran?

c. Apakah community development dan networking secara simultan memberikan pengaruh positif dan signifikan terhadap faktor-faktor keselamatan pelayaran?

\section{Signifikansi Penelitian}

Penelitian ini diharapkan dapat bermanfaat sebagai berikut:

a. Sebagai indikator awal untuk mengukur kualitas sistem informasi manajemen kepelabuhanan dan pelayaran pada keselamatan pelayaran di perusahaan pelayaran Kabupaten Karimun;

b. Sebagai kontribusi untuk membentuk jaminan mutu sistem informasi kepelabuhanan dan pelayaran pada keselamatan pelayaran di perusahaan pelayaran Kabupaten Karimun;

c. Sebagai referensi untuk membangun karakter perusahaan pelayaran guna mengendalikan tingkat bahaya dalam dunia pelayaran, yang sesuai dengan sistem manajemen keselamatan pelayaran yang disebut sebagai ISM Code (International Safety Management Code) yang dikeluarkan oleh IMO (International Maritime Organization), yang merupakan standar yang disusun dari beberapa kesepakatan dan regulasi yang menyangkut keselamatan dan pencegahan pencemaran lingkungan kelautan.

\section{Kajian Riset Sebelumnya}

1. HM Thamrin. AR, Akademi Maritim Djadajat, Manajemen Keselamatan Maritim dan Upaya Pencegahan Kecelakaan Kapal ke titik nol (zero accident). Jurnal Ilmiah WIDYA 116 Volume 3 Nomor 2 September-Desember 2015. Faktor-faktor yang sangat dominan untuk keselamatan pada kapal dan pencegahan kecelakaan kapal adalah : (1) sumber daya manusia, (2) konstruksi kapal itu sendiri serta (3) perawatan kapal yang rutinitas wajib dilaksanakan sesuai dengan prosedur dan peraturan yang berlaku. Salah satu kondisi juga turut mempercepat kecelakaan kapal-kapal di Indonesia adalah para pemilik atau owner 
tersebut hampir semuanya membeli kapal bekas atau second hand, dimana risiko membeli kapal-kapal bekas tersebut akan menimbulkan hight coast atau biaya tinggi karena perawatan kapal bekas biayanya dapat mencapai $50 \%$ dari harga kapal baru. Tujuan penulisan adalah : (1) Ingin mengetahui upaya untuk mencegah terjadinya kecelakaan pada kapal, (2) Ingin mengetahui cara meningkatkan Sumber Daya Pelaut yang baik. Penelitian ini menggunakan metode analisis deskriptif eksploratif. Hasil penelitian adalah : (1) Perbaiki manajemen yang terkait dengan etos kerja para aparat yang bertugas, melakukan koordinasi dengan berbagai pihak seperti BMG, angkatan laut, polisi udara, bea cukai, dan pihak yang terkait lainnya. Segera dilakukan registrasi ulang dan audit nasional terhadap kapal-kapal Indonesia yang masih beroperasi, pemberian kredit lunak terhadap pembelian kapal-kapal baru sehingga kapal-kapal tua yang sudah tidak laik melaut diganti dengan kapal-kapal yang lebih bagus dan dirancang sesuai perkembangan standardisasi internasional. Dengan adanya koordinasi ini, kegiatan monitoring dan control akan menjadi lebih mudah, sehingga kecelakaan dapat diantisipasi. (2). Pelatihan sumber daya pelaut anak buah kapal (ABK), perwira kapal (office dan crew), dilaksanakan dengan sungguh-sungguh dan tanggung jawab serta mempunyai keterampilan dan keahlian dengan berdasarkan sertifikat yang mereka miliki baik Nakhoda, Perwira, dan anak buah kapal.

2. Gede Perwata (2017) dalam penelitiannya berjudul "Peran Distrik dalam Keselamatan Kerja Pelayaran" menyebutkan, bahwa keamanan dan keselamatan pelayaran merupakan faktor yang sangat penting untuk menunjang kelancaran transportasi laut dan mencegah terjadinya kecelakaan dimana penetapan alur pelayaran dimaksudkan untuk menjamin keamanan dan keselamatan pelayaran melalui pemberian koridor bagi kapal-kapal berlayar melintasi perairan yang diikuti dengan penandaan bagi bahaya kenavigasian. Perusahaan/organisasi pelayaran memformulasikan Community Development dalam meningkatkan kerjasama berupa imbalan upah dalam rangka membantu perekonomian masyarakat salah satunya adalah memberikan arahan pencapaian sasaran dan tujuan pembangunan masyarakat secara optimal dan berkelanjutan. Namun tidak menunjukkan pengaruh yang signifikan terhadap adanya networking dengan pihak-pihak lain yang berkompeten. Sehingga dari dasar penelitian ini maka perlu menyelaraskan hubungan Community Development dengan jaringan sehingga bisa membentuk organisasi yang unggul dan kompetitif. 


\section{METODOLOGI}

\section{Tujuan Penelitian}

Penelitian ini bertujuan untuk mengetahui hubungan antara Community development dan Networking secara simultan terhadap faktor-faktor keselamatan pelayaran Kabupaten Karimun.

\section{Tempat dan Waktu Penelitian}

Penelitian ini dilaksanakan pada 4 perusahaan pelayaran di Kabupaten Karimun, dengan waktu penelitian mulai dari tanggal 4 November 2017 sampai dengan tanggal 4 Januari 2018.

\section{Metode dan Disain Penelitian}

Metode yang digunakan dalam penelitian ini adalah metode kuantitatif dengan mengkaji hubungan antara Community development dan Networking terhadap faktor-faktor keselamatan pelayaran pada sistem informasi manajemen kepelabuhanan dan pelayaran Kabupaten Karimunn. Dari hasil pengajian ini didapatkan pembuktian teori yang dibangun dari Community development dan Networking terhadap konsep pembentukan sistem keselamatan pelayaran pada perusahaan pelayaran yang unggul dan kompetitif. Uji statistik yang digunakan adalah Analisis Regresi Komponen Utama dengan pertimbangan untuk mengatasi terjadinya multikolinearitas tinggi antara variabel-variabel bebas (Kadir, 2010).

\section{Populasi dan Sampel}

Populasi target dalam penelitian ini adalah perusahaan pelayaran Kabupaten Karimun, sedangkan populasi terjangkau adalah 4 perusahaan pelayaran yang menggunakan sistem informasi manajemen keselamatan pelayaran (PT. Rempang Sarana Bahari, PT. ASDP Indonesia Ferry (Persero), PT. Sinar Romindo Indah, dan PT. Arena Bahari Tirtatama) Karena jumlah populasi kurang dari 100, maka penulis melibatkan seluruh populsi sebagai responden (36 orang)

\section{Analisis Data}

Sebelum dianalisis lebih jauh, maka terlebih dahulu dilakukan uji instrument penelitian sebagai berikut :

a. Uji Validitas, untuk mengukur ketepatan dan kecermatan suatu alat ukur dalam melakukan fungsi ukurnya. Dengan kata lain bahwa instrument dapat dikatakan mempunyai validitas yang tinggi apabila alat tersebut menjalankan fungsi ukurnya, atau memberikan hasil ukur sesuai dengan maksud dilakukannya pengukuran (Azwar, 2007).Untuk itu akan dilakukan 
dengan analisis item dengan menggunakan metode korelasi Product Moment Pearson, yaitu mengoperasikan skor jawaban yang diperoleh pada masing-masing item dengan skor total dari keseluruhan item Hasi korelasi tersebut harus signifikan berdasarkan ukuran statistic tertentu. Koefisien korelai yang tinggi menunjukkan kesesuaian antara fungsi item dengan fungsi ukur secara keseluruhan atau instrument tersebut valid.

b. Uji Reliabilitas, selain valid instrument penelitian juga harus reliabel (dapat diandalkan). Instrumen tersebut mempunyai hasil yang konsisten, dengan demikian maka instrument ini dapat dipakai dengan aman karena dapat bekerja dengan baik pada waktu yang berbeda dan kondisi yang berbeda pula (Cooper dan Emory, 2006). Dengan kata lain bahwa reliabilitas menunjukkan sejauh mana pengukuran dapat memberikan hasil yang tidak berbeda bila dilakukan pengukuran kembali terhadap subyek yang sama. Dalam penelitian ini akan dilakukan uji reliabilitas konsistensi internal dengan menggunakan koefisien Alpha Cronbach $(\alpha)$. Suatu instrument dapat disebut reliabel apabila lebih besar dari 0,60.

Adapun analisis data yang digunakan adalah analisis regresi linier berganda.

a.. Model Analisis

Rumus

$\mathrm{Y}=\mathrm{a}+\mathrm{b} 1 \mathrm{X} 1+\mathrm{b} 2 \mathrm{X} 2$.

Dimana :

$\mathrm{Y} \quad=$ Faktor-faktor Keselamatan Pelayaran

a $\quad=$ Koefisien Regresi (konstanta)

b1 = Koefisien Regresi Variabel X1

b2 = Koefisien Regresi Variabel X2

$\mathrm{X} 1=$ Community Development

$\mathrm{X} 2 \quad=$ Networking

b. Tahap Analisis

1). Analisis Regresi linier berganda untuk mengetahui faktor-faktor apa saja yang mempengaruhi keunggulan kompetitif keselamatan pelayaran Kabupaten Karimun sebagai penduga awal.

2). Uji asumsi-asumsi agar diperoleh model yang tak bias, konsisten dan efisien.

Asumsi-asumsi tersebut diantaranya: 
a) Multikolinearitas

Pada tahap ini dilihat nilai R2 (koefisien determinasi) dan nilai VIF (Variance inflation Factor) serta dilakukan uji individu terhadap parameter model. Apabila terjadi kasus multikolinieritas maka diselesaikan dengan regresi Stepwise (Stepwise regression).

b) Heterokedastisitas

Pada tahap ini, untuk mengetahuinya digunakan uji Glejser. Apabila ditemukan kasus heteroskedastisitas maka solusinya adalah melakukan transformasi terhadap variabel.

c) Berdistribusi Normal

Untuk memeriksa kenormalan dapat digunakan uji Kolmogorov-Smirnov yaitu dengan membandingkan Pvalue statistic Kolmogorov-Smirnov dengan $\alpha=0,05$.

Setelah diperoleh model regresi yang sudah memenuhi beberapa asumsi klasik yang telah ditetapkan, maka dari model akhir tersebut dilakukan analisis dan kemudian dibuat kesimpulan.

\section{Hipotesis Statistik}

1. Uji Signifikansi Persamaan Regresi Ganda

a. Uji Signifikan Parameter Regresi Ganda

Dimana $\beta$ adalah koefisien regresi dan $\mathrm{j}$ adalah variabel $\mathrm{X} 1$ dan $\mathrm{X} 2$

b. Uji Individual Parameter Regresi ganda

\section{Uji Sigifikansi Korelasi}

a. Uji Signifikansi Koefisien Korelasi Ganda

Dimana $\rho$ adalah korelasi

b. Uji Signifikansi Korelasi Parsial

1) Korelasi $Y$ dengan $X 1$

2) Korelasi $Y$ dengan $X 2$

3) Korelasi $X 1$ dengan $X 2$

\section{(1). Validitas dan Reliabilitas Alat Ukur}

Menurut Sugiyono (2018) instrumen yang valid berarti alat ukur yang digunakan untuk mendapatkan data (mengukur) itu valid. Valid berarti instrument tersebut dapat digunakan untuk mengukur apa yang seharusnya diukur.

Untuk mengetahui validitas suatu item atau indikator, maka dilakukan perhitungan dengan menggunakan teknik korelasi product moment, diperoleh hasil bahwa semua item pertanyaan dari dua variabel bebas yaitu Community development dan Networking dan 
variabel terikat Faktor-faktor keselamatan pelayaran yang diajukan kepada responden mempunyai korelasi yang lebih tinggi dari $r$ tabel $(n=36$, sign=5\%, $r=0,2785)$. Dengan demikian bisa dikatakan bahwa semua indikator pengukuran yang dipergunakan dalam penelitian ini memiliki validitas yang layak, sehingga analisis lebih lanjut dapat dilakukan.

Tabel 1 Hasil Uji Validitas

\begin{tabular}{|c|c|c|c|}
\hline No & Variabel & Item & Koefisien Korelasi \\
\hline 1 & Community development (X1) & $\begin{array}{c}\text { X1.1 } \\
\text { X1.2 } \\
\text { X1.3 } \\
\text { X1.4 } \\
\text { X1.5 } \\
\text { X1.6 } \\
\text { X1.7 } \\
\text { X1.8 } \\
\text { X1.9 } \\
\text { X1.10 } \\
\text { X1.11 }\end{array}$ & $\begin{array}{c}0,565 \\
0,547 \\
0, .605 \\
0, .340 \\
0, .637 \\
0,456 \\
0, .613 \\
0, .715 \\
0,557 \\
0,729 \\
0,561\end{array}$ \\
\hline 2 & Networking (X2) & $\begin{array}{l}\text { X2.1 } \\
\text { X2.2 } \\
\text { X2.3 } \\
\text { X2.4 } \\
\text { X2.5 } \\
\text { X2.6 } \\
\text { X2.7 } \\
\text { X2.8 } \\
\text { X2.9 } \\
\text { X2.10 } \\
\text { X2.11 } \\
\text { X2.12 }\end{array}$ & $\begin{array}{c}0,595 \\
0,400 \\
0,626 \\
0, .551 \\
0,415 \\
0,792 \\
0,674 \\
0,774 \\
0,774 \\
0,812 \\
0,752 \\
0,616\end{array}$ \\
\hline
\end{tabular}




\begin{tabular}{|l|l|r|r|}
\hline 3 & Faktor-faktor keselamatan & Y1 & 0,582 \\
& pelayaran (Y) & Y2 & 0,722 \\
& & Y3 & $0, .492$ \\
& & Y4 & $0, .690$ \\
& Y5 & 0,744 \\
& Y6 & $0, .644$ \\
& Y7 & $0, .550$ \\
& Y8 & $0, .666$ \\
& Y9 & 0,491 \\
& Y10 & 0,588 \\
& Y11 & 0,668 \\
& Y12 & 0,711 \\
& Y13 & 0,445 \\
& Y14 & 0,764 \\
& Y15 & 0,778 \\
& Y16 & 0,717 \\
& Y17 & 0,693 \\
& Y18 & 0,855 \\
\hline
\end{tabular}

Sumber : Hasil penelitian diolah, 2018

Instrumen yang reliabel adalah instrument yang bila digunakan beberapa kali untuk mengukur obyek yang sama, akan menghasilkan data yang sama (Sugiyono, 2018). Koefisien reliabilitas diketahui dari besarnya koefisien alpha $(\alpha)$. Dengan bantuan komputer program SPSS 17.0, diketahui bahwa koefisien reliabilitas alat ukur dalam penelitian ini dapat terlihat pada Tabel 5.2 Reliabilitas dikatakan baik apabila besarnya alpha mendekati nilai 1, sehingga item-item pertanyaan dalam penelitian ini dapat diandalkan. hal tersebut sesuai pendapat Maholtra (1996) yang mengatakan bahwa kriteria reliabilitas alpha $(\alpha)$ dikatakan reliabel apabila koefisien aalpha $(\alpha)$ lebih besar dari 0,6 , tetapi apabila sebaliknya koefisien alpha $(\alpha)$ lebih kecil atau kurang dari 0,6 menunjukkan tidak adanya konsistensi jawaban responden.

\section{Tabel 2 Hasil Uji Reliabilitas}

\begin{tabular}{|c|c|c|}
\hline VARIABEL & ALPHA & PENILAIAN \\
\hline $\mathrm{X} 1$ & 0,799 & Reliabel \\
\hline $\mathrm{X} 2$ & 0,875 & Reliabel \\
\hline $\mathrm{Y}$ & 0,904 & Reliabel \\
\hline
\end{tabular}

Sumber : Kuesioner diolah, 2018 
Berdasarkan nilai reliabilitas alpha $(\alpha)$ yang lebih besar dari 0,6, maka dapat dikatakan bahwa semua variabel bebas dalam penelitian ini adalah mantap atau reliabel. Untuk variabel terikat yaitu faktor-faktor keselamatan pelayaran nilai reliabilitas alpha $(\alpha)$ sebesar 0,904, dengan demikian penilaian ini disimpulkan reliabel.

(2). Analisis Model dan Pembuktian Hipotesis

a. Analisis Model

Model analisis yang digunakan adalah analisis regresi linier berganda dengan faktorfaktor keselamatan pelayaran sebagai variabel terikat. Sementara variabel bebasnya adalah Community development (X1) dan Networking (X2). Perhitungan regresi serta perhitungan lain yang mendukung dalam penelitian ini dilakukan dengan menggunakan program SPSS 17.0

Tabel 3 Ringkasan Hasil Analisis Regresi Berganda

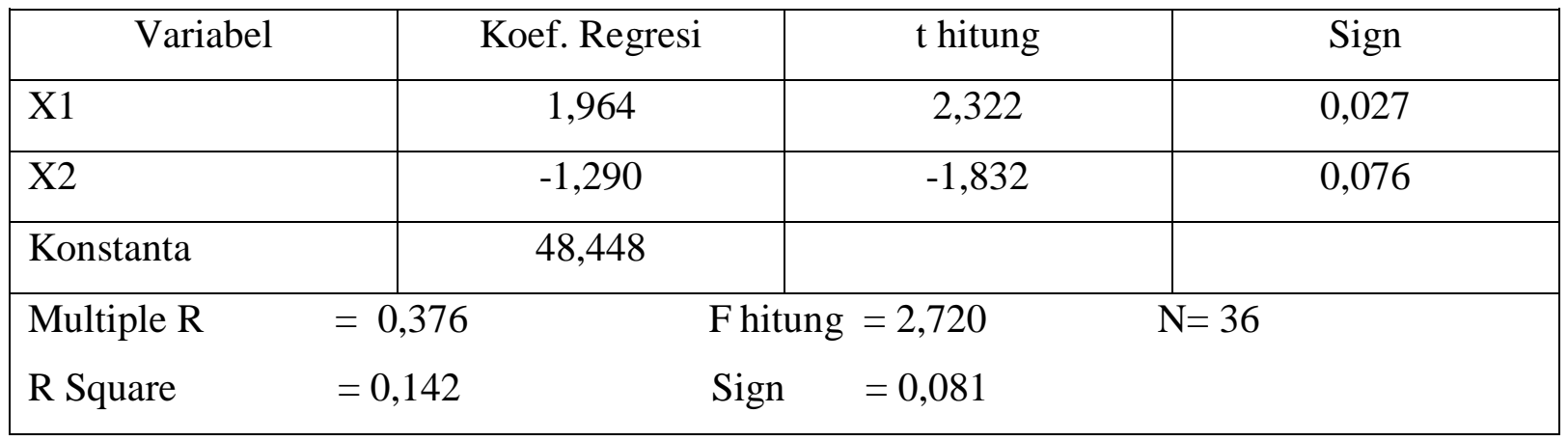

Sumber : Lampiran (Analisis Statistik), 2018

Berdasarkan hasil perhitungan, maka dapat disusun suatu formulasi regresi linier berganda seperti berikut :

$$
\mathrm{Y}=48,448+1,964 \mathrm{X} 1-1,290 \cdot \mathrm{X} 2
$$

Persamaan di atas dapat dijelaskan sebagai berikut :

1) Apabila Community Development (X1) berubah 1, maka Faktor-faktor Keselamatan Pelayaran (Y) akan berubah sebesar 1,964 artinya apabila Community Development (X1) naik, maka Faktor-faktor Keselamatan Pelayaran (Y) akan naik, begitu pula apabila Community Development (X1) menurun, maka Faktor-faktor Keselamatan Pelayaran (Y) akan turun, dengan asumsi X2 tetap.

2) Apabila Networking (X2) berubah 1, maka Faktor-faktor Keselamatan Pelayaran (Y) akan berubah sebesar -1,290 artinya apabila Networking (X2) naik, maka Faktor-faktor 
Keselamatan Pelayaran (Y) akan turun, begitu pula apabila Networking (X2) menurun, maka Faktor-faktor Keselamatan Pelayaran (Y) akan naik dengan asumsi X1 tetap.

3). Tetapi jika sikap responden terhadap Community Development (X1) dan Networking (X2) adalah nol, maka besarnya Faktor-faktor Keselamatan Pelayaran (Y) adalah 48,448

Sementara hasil analisis terhadap Tabel 5.3 dapat dijelaskan sebagai berikut :

(a) Koefisien korelasi berganda (multiple R) menunjukkan bahwa kekuatan hubungan antara variabel bebas yang terdiri dari Community development (X1) dan Networking (X2) dengan variabel terikat yaitu faktor-faktor keselamatan pelayaran (Y) secara bersamasama adalah sebesar 0,376, sementara arah hubungan positif variabel bebas tersebut mempunyai hubungan searah dengan variabel terikatnya, maksudnya jika nilai variabel bebas meningkat atau ditingkatkan, maka akan mendorong meningkatnya Faktor-faktor keselamatan Pelayaran di Perusahaan Pelayaran Kabupaten Karimun, sebaliknya dengan arah hubungan negatif variabel bebas terhadap variabel terikatnya.

(b). Nilai R Square $\left(\mathrm{R}^{2}\right)$ atau koefisien determinasi sebesar 0,142. Hal ini berarti sebesar 14,2 \% Faktor-faktor Keselamatan Pelayaran di Perusahaan Pelayaran Kabupaten Karimun secara bersama-sama dipengaruhi oleh Community development (X1) dan Networking (X2). Nilai ini dapat dikatakan rendah, karena menurut Rietveld dan Sumary (1994) untuk penelitian social, $\mathrm{R}^{2}$ antara $0,4-0,6$ sudah dapat dikatakan tinggi.

b. Uji Asumsi Klasik

Dalam model regresi linier terdapat beberapa asumsi yang harus dipenuhi, diantaranya:

1. Tidak boleh ada atau terjadi autokorelasi antara kesalahan-kesalahan pengganggu.

2. Tidak ada multikolinearitas antara variabel bebas.

3. Tidak boleh terjadi heterokedastisitas.

4. Berdistribusi normal.

Tetapi dalam penelitian ini hanya terbataskan pada tiga uji asumsi klasik, yaitu uji multikolinearitas, uji heterokedastisitas, dan uji normalitas.

\section{Pengujian Multikolinearitas}

Berdasarkan hasil perhitungan SPSS 17.0 menunjukkan bahwa nilai Variance Inflation Factor (VIF) dari semua variabel bebas yang terdiri dari Community development dan Networking menunjukkan nilai lebih kevil dari 10, artinya persoalan multikorelasi diantara variabel bebas tidak terjadi. 
Tabel 4 Koefisien Variance Inflation Factor

\begin{tabular}{|l|c|}
\hline \multicolumn{1}{|c|}{ Variabel } & Variance Inflation Factor \\
\hline Community development (X1) & 3,424 \\
\hline Networking (X2) & 3,424 \\
\hline
\end{tabular}

Sumber : Data diolah, 2018

\section{Pengujian Heterokedastisitas}

Apabila terjadi heterokedastisitas berarti ada hubungan antara variabel pengganggu dengan variabel terikatnya, sehingga dengan demikian variabel terikat tidak benar-benar hanya dijelaskan oleh variabel bebas yang dipakai, tetapi juga oleh variabel pengganggunya. Menurut Ghozali (2009), uji heterokedastisitas bertujuan untuk menguji apakah dalam model regresi terjadi ketidak samaan varians dari residual datu pengamatan ke pengamatan lain. Jika varians dari satu pengamatan ke pengamatan lain tetap, maka disebut homokedastisitas atau tidak terjadi heterokedastisitas. Model regresi yang baik adalah yang homokedastisitas atau tidak terjadi heterokedastisitas.

Deteksi ada tidaknya heterokedastisitas dapat dilakukan dengan melihat grafik plot antara nilai prediksi variabel terikat (dependent variable), yaitu ZPRED dengan residualnya SRESID. Deteksi ada tidak adanya heterokedastisitasnya dapat dilakukan dengan melihat adanya pola tertentu pada grafik scatterpol antara ZPRED dan SRESID dimana sumbu Y adalah yang telah diprediksi dan sumbu X residual (Y prediksi-Y sesungguhnya) yang telah di studentized (Ghozali, 2009).

\section{Pengujian Normalitas}

Uji normalitas bertujuan untuk menguji apakah dalam suatu model regresi linier, variabel terikat dan variabel bebas keduanya mempunyai distribusi normal (Ghozali, 2009). Alat analisis yang digunakan dalam uji ini adalah uji Kolmogorov-Smirnov satu arah dan analisis grafis. Dasar pengambilan keputusan uji Kolmogorov-Smirnov normal atau tidaknya data yang diolah adalah sebagai berikut (Ghozali, 2009) :

1. H0 : Data residual berdistribusi normal apabila nilai signifikan $>5 \%(0,05)$.

2. H1 : Data residual tidak berdistribusi normal apabila nilai signifikan $<5 \%(0,05)$.

Dasar pengambilan keputusan uji grafik normal atau tidaknya data yang diolah adalah sebagai berikut (Ghozali, 2009) : 
1. Jika data menyebar disekitar garis diagonal dan mengikuti arah garis diagonal atau grafik histogramnya, menunjukkan pola terdistribusi normal, maka model regresi memenuhi asumsi normalitas.

2. Jika data menyebar jauh dari garis diagonal dan tidak mengikuti arah garis diagonal atau grafik histogramnya, tidak menunjukkan pola terdistribusi normal, maka model regresi tidak memenuhi asumsi normalitas.

Dari hasil uji Kolmogorov-Smirnov dengan membandingkan Pvalue Statistic Kolmogorov-Smirnov $\alpha=0,05$, maka diperoleh nilai 1,023 artinya data terdistribusi secara normal (hasil olahan data dalam bentuk grafik terlampir)

\section{Pengujian Hipotesis}

\section{1). Pengujian Hipotesis Pertama dan Kedua}

Hipotesis pertama adalah terdapat pengaruh positif dan signifikan dari community development terhadap faktor-faktor keselamatan pelayaran, sedangkan hipotesis kedua adalah terdapat pengaruh positif dan signifikan dari networking terhadap faktor-faktor keselamatan pelayaran. Pengujian kedua hipotesis ini dengan menggunakan uji t.

Tabel 5 Hasil Perhitungan Uji t

\begin{tabular}{|c|c|c|c|}
\hline Variabel & thitung & Sign & $\mathrm{t}$ tabel \\
\hline $\mathrm{X} 1$ & 2,322 & 0,027 & 2,035 \\
\hline $\mathrm{X} 2$ & $-1,832$ & 0,076 & 2,035 \\
\hline
\end{tabular}

Sumber : Data primer diolah, 2018

Derajat kebebasan $\mathrm{df}=(\mathrm{n}-\mathrm{k}-1)=36-2-1=33$ dan tingkat taraf kepercayaan 5\% atau 0.05, maka nilai $\mathrm{t}$ tabel adalah sebesar 2, 035. Nilai t hitung X1 sebesar 2,322 dengan tingkat signifikansi 0,027 lebih besar dari nilai t tabel sebesar 2,035. Hal ini menunjukkan bahwa terjadi penolakan Ho dan penerimaan Ha , yang berarti terdapat pengaruh yang positif dan signifikan variabel Community development terhadap variabel faktor-faktor keselamatan pelayaran di perusahaan pelayaran Kabupaten Karimun. Sedangkan nilai t hitung X2 sebesar -1,832 dengan tingkat signifikansi 0,076 lebih kecil dari nilai t tabel sebesar 2,035. Hal ini menunjukkan bahwa terjadi penerimaan Ho dan penolakan Ha, yang berarti tidak terdapat pengaruh yang positif dan signifikan variabel Networking terhadap variabel faktor-faktor keselamatan pelayaran di perusahaan pelayaran Kabupaten Karimun. 


\section{2). Pengujian Hipotesis Ketiga}

Pengujian hipotesis yang ketiga ini dengan menggunakan uji $\mathrm{F}$ dengan dasar pengambilan keputusan :

a. $\mathrm{H}_{0}: \mathrm{F}_{\text {hitung }}>\mathrm{F}_{\text {tabel }}$, berarti $\mathrm{H}_{0}$ ditoak dan $\mathrm{H}_{\mathrm{a}}$ diterima

Hal ini menunjukkan bahwa terdapat pengaruh secara simultan antara variabel X1 dan X2 dengan variabel Y.

b. $\mathrm{H}_{\mathrm{a}}: \mathrm{F}_{\text {hitung }}<\mathrm{F}_{\text {tabel }}$, berarti menerima $\mathrm{H}_{0}$ dan menolak $\mathrm{H}_{\mathrm{a}}$

Hal ini menunjukkan bahwa tidak terdapat pengaruh secara simultan antara variabel X1 dan X2 dengan variabel Y.

Tabel 6 Hasil Perhitungan Uji Simultan (Uji F)

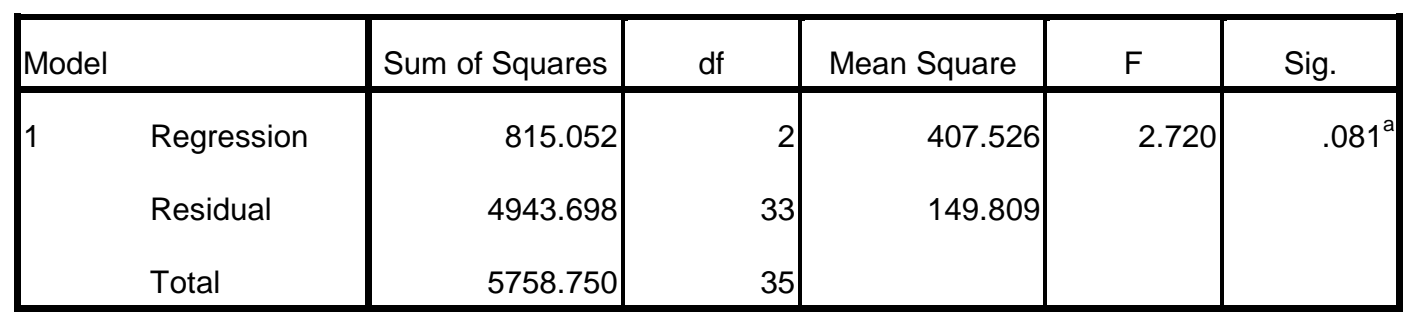

a. Predictors: (Constant), X2, X1

b. Dependent Variable: $Y$

Sumber : Data primer diolah, 2018

Perhitungan regresi linear berganda menghasilkan nilai $F_{\text {hitung }}$ sebesar 2,720 dan $F_{\text {tabel }}$ sebesar 3,28. Dengan demikian, maka terbukti bahwa $\mathrm{F}_{\text {hitung }}$ lebih kecil daripada $\mathrm{F}_{\text {tabel }}$ yang berarti $\mathrm{H}_{0}$ diterima dan menolak $\mathrm{H}_{\mathrm{a}}$ pada tingkat signifikansi sebesar 0.000 , artinya bahwa tidak terdapat pengaruh yang signifikan variabel-variabel bebas secara simultan (bersama-sama) terhadap variabel terikat. Dengan begitu hipotesis ketiga ini tidak terbukti kebenarannya.

\section{PEMBAHASAN}

Perkembangan sistem informasi manajemen telah menyebabkan terjadinya perubahan yang cukup signifikan dalam pola pengambilan keputusan yang dilakukan oleh manajemen baik pada tingkat operasional (pelaksana teknis) maupun pimpinan pada semua jenjang. Perkembangan ini juga telah menyebabkan perubahan-perubahan peran dari para manajer dalam pengambilan keputusan. Mereka dituntut untuk selalu dapat memperoleh informasi yang paling akurat dan terkini yang dapat digunakannya dalam proses pengambilan keputusan. 
Hal ini sesuai dengan pendapat Kurniawan, R (2017) yang mengatakan, bahwa perkembangan informasi teknologi secara terus menerus mengubah dunia bisnis. Manajemen teknologi informasi perusahaan juga telah berubah dengan menggunakan jaringan digital yang berkecepatan tinggi. Dengan berkembangnya sistem informasi yang begitu cepat seorang manajer bisa bekerja dengan menggunakan akses on-line yang bisa digunakan lebih cepat untuk mengetahui perkembangan informasi perusahaan.

Seiring dengan perusahaan memebuhi kebutuhan produk dan jasa para pelanggan, perusahaan tersebut akan berusaha untuk mendapatkan keunggulan di atas para pesaingnya. Mereka dapat mencapai keunggulan ini dengan memberikan produk dan jasa pada harga yang lebih rendah, memberkan produk dan jasa dengan kualitas yang lebih tinggi dan memenuhi kebutuhan-kebutuhan khusus dari segmen-segmen pasar tertentu. Keunggulan kompetitif dapat diperoleh melalui pengolahan sumber daya fisik dan sumber daya virtual

Sebuah perusahaan adalah suatu sistem fisik yang dikelola melalui penggunaan sistem virtual. Sistem fisik perusahaan merupakan suatu sistem terbuka dimana ia berhadapan dengan lingkungannya. Sebuah perusahaan mengambil sumber daya dari lingkungannya, mengubah sumber daya tersebut menjadi produk dan jasa dan mengembalikan sumber daya yang telah diubah kembali ke lingkungan.

Model sistem umu sebuah perusahaan membuat kita dapat dengan mudah melihat arti penting lingkungan bagi kesuksesan sebuah perusahaan. Sebuah perusahaan tercipta atas dasar tujuan untuk memberikan produk dan jasa yang memenuhi kebutuhan lingkungannya. Sama pentingnya sebuah perusahaan tidak akan dapat berfungsi tanpa sumber daya yang diberikan oleh lingkungannya.

Lingkungan dapat bervariasi dari satu perusahaan ke perusahaan lainnya. Unsur-unsur lingkungan ini adalah organisasi dan individu yang berada di luar perusahaan dan memilii pengaruh langsung maupun tidak langsung atas perusahaan, unsur yang lebih besar disebut masyarakat. Community development diartikan sebagai kegiatan pengembangan masyarakat yang diarahkan untuk memperbesar akses masyarakat untuk mencapai kondisi socialekonomi-budaya yang lebih baik apabila dibandingkan dengan sebelum adanya kegiatan pembangunan. Sehingga masyarakat di tempat tersebut diharapkan menjadi lebih mandiri dengan kualitas kehidupan dan kesejahteraan yang lebih baik.

Faktor community development memberikan pengaruh yang besar di dalam memperkuat eksistensi dan peningkatan pertumbuhan dan perkembangan sistem informasi 
manajemen keselamatan pelayaran, dimana dengan sistem informasi manajemen yang baik dan unggul maka perusahaan pelayaran dapat mengetahui bagaimana perilaku social dan lingkungan sekitarnya.

Perusahaan terhubung dengan unsur-unsur lingkungannya melalui aliran sumber daya lingkungannya. Pada perusahaan pelayaran aliran yang terjadi adalah aliran informasi kepada pelanggannya., dan perusahaan berusaha untuk menjadikan hubungan informasi dengan pesaing sebagai suatu aliran satu arah.

Dengan adanya informasi yang tepat dan cepat, maka informasi tentang pelayaran (di laut) dan pengurusan dokumen-dokumen di darat (perusahaan) dapat dilakukan lebih cepat. Semakin banyak informasi yang diperoleh, maka masyarakat akan semakin terpuaskan. Dari sinilah dapat dilihat bagaimana respon masyarakat terhadap perusahaan, apakah mereka tertarik untuk memakai jasa perusahaan pelayaran tersebut atau tidak. Karena semakin bermutu (unggul) suatu perusahaan pelayaran terutama di bidang keselamatan pelayarannya, maka semakin tinggi minat masyarakat untuk memakai jasa perusahaan pelayaran tersebut. Disinilah peran perusahaan pelayaran dalam meningkatkan mutu perusahaannya sehingga nantinya dapat memenuhi kebutuhan masyarakat, baik dalam hal transportasi laut maupun alur lalu lintas barang/dagangan yang akhirnya dapat meningkatkan perekonomian daerah.

Tingkat kepercayaan masyarakat yang tinggi terhadap suatu perusahaan pelayaran dapat mempengaruhi tingkat kompetitif/persaingan antar perusahaan pelayaran yang ada di Kabupaten Karimun. Bila dilihat dari faktor kemitraan (networking) yang menunjukkan tidak adanya pengaruh positif dan signifikan terhadap sistem informasi manajemen keselamatan pelayaran, diduga karena sistem manajemen yang digunakan masih secara manual namun sudah terkomputerisasi dalam pengurusan dokumen kedatangan maupun keberangkatan kapal. Informasi yang dibutuhkan masih lambat dan tidak optimal, sehingga antara perusahaan yang satu dengan perusahaan yang lainnya kurang komunikasi, sibuk dengan urusan masing-masing. Disamping itu, adanya persaingan antar perusahaan pelayaran bisa menjadi penyebab kurangnya kerjasama antar perusahaan.

Dengan sistem informasi manajemen yang unggul dan kompetitif, perusahaan pelayaran di Kabupaten Karimun mempunyai kesempatan/potensi yang besar dalam memberdayakan masyarakat sekitar, mislnya dengan memanfaatkan media social yang saat ini berkembang pesat dan memberikan dampak yang sangat besar bagi penyebaran informasi di tengah-tengah masyarakat. Informasi dapat disampaikan dengan cepat dan menyentuh 
segala lapisan masyarakat. Tergantung lagi bagaimana manajemen perusahaan untuk menarik minat masyarakat dengan strateginya masing-masing, sehingga tujun perusahaan tercapai.

Semakin baik manajemen perusahaan pelayaran dalam pengelolaan, pengontrolan maupun pengembangan perusahaannya, maka semakin besar pua dampak/pengaruhnya bagi masyarakat dan lingkungan sekitarnya. Bagi perusahaan pelayaran yang sudah maju, tentu saja ditentukan oleh sistem manajemennya, dapat memberikan bantuan kepada masyarakat sekitar berupa dana social (bantuan Corporate Social Responsibility/CSR, sesuai pendapat Nuryana dalam Fahmi, I (2017). Cara seperti ini sudah dibuktikan dapat menarik masyarakat untuk tetap memakai jasa perusahaan pelayaran yang memberikan bantuan tersebut, bahkan dapat meningkatkan jumlah pelanggannya.

Disamping itu dengan adanya sistem perekrutan karyawan dari lingkungan masyarakat sekitar, akan lebih memberikan pengaruh yang positif terhadap perusahaan. Akan memberikan nilai plus bagi perusahaan, sehingga masyarakat akan memilihnya sebagai pelayan angkutan lautnya Sistem informasi keselamatan pelayaran yang akurat yang disampaikan kepada masysrakat sangat bermanfaat bagi perusahaan pelayaran, dimana inforamsi tersebut juga mempengaruhi tingkat persaingan diantara perusahaan pelayaran yang ada di Kabupaten Karimun. Semakin kecil tingkat kecelakaan pelayaran yang terjadi di dalam operasional pelayaran kapal yang dioperasikan oleh sebuah perusahaan pelayaran, maka akan semakin tinggi tingkat kepercayaan masyarakat untuk memakai jasa angkutan laut yang dimiliki oleh perusahaan tersebut. Disinilah kaitannya antara sistem informasi manajemen dengan sistem informasi tentang keselamatan pelayaran perusahaan pelayaran.

\section{KESIMPULAN}

Berdasarkan hasil analisa dan pembahasan penelitian di atas, maka penulis dapat mengambil beberapa kesimpilan sebagai berikut :

a. Kualitas Sistem Informasi Manajemen (SIM) keselamatan pelayaran di perusahaan pelayaran Kabupaten Karimun masih belum optimal, dimana perusahaan masih memakai sistem manual (komputerisasi tapi belum on-line), sehingga informasi yang disampaikan kepada masyarakat kurang optimal (lambat).

b. Jaminan mutu SIM keselamatan pelayaran di perusahaan pelayaran Kabupaten Karimun masih belum semuanya memenuhi standar yang ditetapkan, bahkan ada yang belum memiliki standardisasi mutu sehingga perlu dibuat dan lebih ditingkatkan lagi. 
c. Perlu ditingkatkan lagi karakter perusahaan pelayaran yang ada di Kabupaten Karimun, sehingga terbentuk perusahaan pelayaran yang unggul dan kompetitif di tingkat nasional maupun internasional.

d. Dari hasil analisa uji $\mathrm{t}$ diperoleh kesimpulan, bahwa variabel bebas community development (X1) berpengaruh positif dan signifikan terhadap variabel terikat faktorfaktor keselamatan pelayaran (Y), dimana nilai t hitung (2,322) dengan signifikansi 0,027 $>$ dari nilai t tabel (2.035), sedangkan variabel bebas networking (X2) tidak berpengaruh positif dan signifikan terhadap variabel terikat faktor-faktor keselamatan pelayaran (Y) dimana nilai t hitung $(-1,832)$ dengan signifikansi $0,076<$ dari nilai t tabel $(2,035)$. Sementara dari hasil uji f diperoleh kesimpulan, bahwa variabel bebas community development (X1) dan networking (X2) tidak berpengaruh secara bersama-sama (simultan) terhadap variabel terikat faktor-faktor keselamatan pelayaran (Y), dimana nilai f hitung $(2,720)$ dengan signifikansi $0,081<$ dari nilai $\mathrm{f}$ tabel $(3,28)$.

\section{REFERENSI}

Arbie, E. 2011. Pengantar Sistem Informasi Manajemen. Penerbit Raya, Jakarta.

Andrew, H. 2009. Kekuatan Networking. (Dalam http//pembelajar.com, tanggal 27 Januari 2017).

Bungin, B. 2009. Metodologi Penelitian Kuantitatif. Penerbit Kencana Prenada Media Group, Jakarta.

Ghozali, I. 2009. Aplikasi Analisis Multivariate dengan IBM SPSS 21, Badan Penerbit Universitas Diponegoro, Semarang

Mustaqim, S. 2008. Penguatan Masyarakat dengan Program CDA. (Dalam http//1.blog.spot.com. tanggal 27 Februari 2017).

Kadir. 2010. Statistika untuk Penelitian Ilmu-ilmu Sosial. Penerbit Rosemata Sampurna, Jakarta.

Kertahadi. 2007. Dasar-dasar Sistem Informasi. STIKOM, Yogyakarta.

Kurniawan, R. 2017. Sistem Informasi Manajemen, Membuat Aplikasi Pegawai. UMRAH Press, Tanjung Pinang.

Siagian, S.P. 2016. Sistem Informasi Manajemen. Ed.2 Cet.12. Bumi Aksara, Jakarta.

Sugiyono. 2018. Metode Penelitian Kuantitatif, CV. Alfabeta, Bandung.

Sutabri, T. 2012. Analisa Sistem Informasi,. Penerbit Andi Offset, Yogyakarta. 
Wibisono, Y. 2007. Membedah Konsep dan Aplikasi CSR. Penerbit Fascho Publishing, Gresik. 